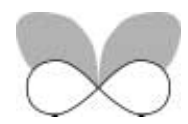

\title{
The illusion of preservation: a global environ- mental argument for the local production of natural resources
}

Mary M. Berlik, David B. Kittredge* and David R. Foster Harvard Forest, Harvard

University, Petersham, MA, USA

\section{Abstract}

Aim The United States (US) and other affluent countries consume vast quantities of global natural resources, but contribute proportionately less to the extraction of many raw materials. This imbalance is due, in part, to domestic policies intended to protect the environment. Ironically, developed nations are often better equipped to extract resources in an environmentally prudent manner than the major suppliers. Thus, although citizens of affluent countries may imagine that preservationist domestic policies are conserving resources and protecting nature, heavy consumption rates necessitate resource extraction elsewhere and oftentimes under weak environmental oversight. A major consequence of this 'illusion of natural resource preservation' is greater global environmental degradation than would arise if consumption were reduced and a large portion of production was shared by affluent countries. This paper considers some implications of the consumption, management and conservation of forests and wood at a local and global scale.

Location We focus on Massachusetts, the eighth most forested state in the USA (by area), the third most densely populated, and an affluent region with consumption rates that are among the highest in the country.

Methods Estimates of wood production and consumption are generated, and comparisons are made with other commonly used materials (e.g. steel, concrete, aluminium).

Results A comparison of the feasibility and environmental impact of various strategies for dealing with rising wood demand suggests that the US should strive to: (1) reduce per capita consumption of wood and its substitutes, (2) recycle forest products more effectively, (3) protect extensive areas of intensively managed and unmanaged forests and (4) promote sound forest management where the environmental consequences are mild. Forestry and the sustainable generation of wood in Massachusetts would allow preservation of primary forests elsewhere in the world.

Main conclusions When aggressive reductions in wood consumption and effective recycling are combined with judiciously increased harvest levels, $50 \%$ of the Massachusetts's wood consumption could be met at sustainable rates, even while preserving large undisturbed blocks of forest.

\section{Keywords}

Wood, consumption, production, sustainability, preservation, nature.

\footnotetext{
*Correspondence: Harvard Forest, Harvard University, Petersham, MA 01366 USA. E-mail: dbk@forwild.umass.edu
} 


\section{THE ILLUSION - A CLASH BETWEEN LOCAL CONSUMPTION AND GLOBAL PROTECTION}

As a nation of affluent consumers, the United States (US) appropriates a large portion of the world's resources. As a nation of environmentally aware citizens, the US champions nature protection, especially within its borders. Notably and hypocritically, the protectionist attitude often fails to address the link between high levels of domestic consumption and the unavoidable impacts this imposes on the global environment, especially beyond US borders. In addition to the tangible issue of whether humankind can live sustainably within the earth's ecological limits, there is an environmental question of whether the burden of natural resource production should be placed on remote and oftentimes fragile landscapes, and the intriguing sociological question of whether affluent citizens might alter their patterns of resource consumption if the environmental consequences of this behaviour was apparent in their own backyards.

To support high levels of consumption, the US relies heavily on imported raw materials. Concomitantly, the American public is increasingly interested in reducing domestic resource use in order to protect the natural environment (Bowyer, 1994; Bowyer \& Stockman, 2001). This attitude frequently ignores the fact that reducing domestic production with no corresponding change in consumption simply requires other parts of the globe to supply the resources. Consequently, well-intentioned environmental activism may generate unanticipated environmental degradation if it fails to recognize that natural resource preservation is but an illusion if it only serves to shift the source of resources, especially to locations where extraction is less environmentally sound. In order to achieve true environmental protection, it is essential to consider both consumption and the global distribution of resource production. This principle can be highlighted through a focus on a major resource and a critical global environment - wood and the world's forests.

\section{Global wood needs}

The environmental impacts of wood extraction depend on the condition and sensitivity of the targeted forest and the management approach. Consequently, it is critical to focus on where and how wood is actually harvested. In principle, wood is a renewable resource, but in the absence of wellplanned management, short-term exploitation can induce environmental impacts or conversion to other uses yielding results better likened to mining than sustainable use (Allen, 1998a,b).

Although much of the world is forested, consumption growth rates are jeopardizing the reliability of the global wood supply (Solberg et al., 1996; Dekker-Robertson \& Libby, 1998; Bowyer \& Stockman, 2001). Global annual wood harvests average about 3.4 billion $\mathrm{m}^{3}$. With mean projections for 2010 of 4.6 billion $\mathrm{m}^{3}$ (a $35 \%$ increase in 10 years), a shrinking amount of forest will need to provide increasing volumes of wood. Current projections forecast a gap between global fibre demand and availability of 400800 million $\mathrm{m}^{3}$ in 2010 (World Resources Institute 1998).

\section{The consequences of US attitudes and policies towards forest protection policies}

Affluent nations are implementing ever-stricter policies to limit and control logging, ranging from public land management reforms to logging bans (Dekker-Robertson \& Libby, 1998). In the US these activities are shifting harvesting regionally and overseas. For example, in the Pacific North-west, national policies have reduced production to 20\% of 1980-89 levels (Dekker-Robertson \& Libby, 1998). Some of this decline has been offset by increased harvesting in the South-eastern US, but imports from Canada, South America, South-east Asia, South Africa and Russia have grown and continue to increase (ITTO, 1999; Tromborg et al., 2000; World Forest Institute, 2000; Fig. 1).
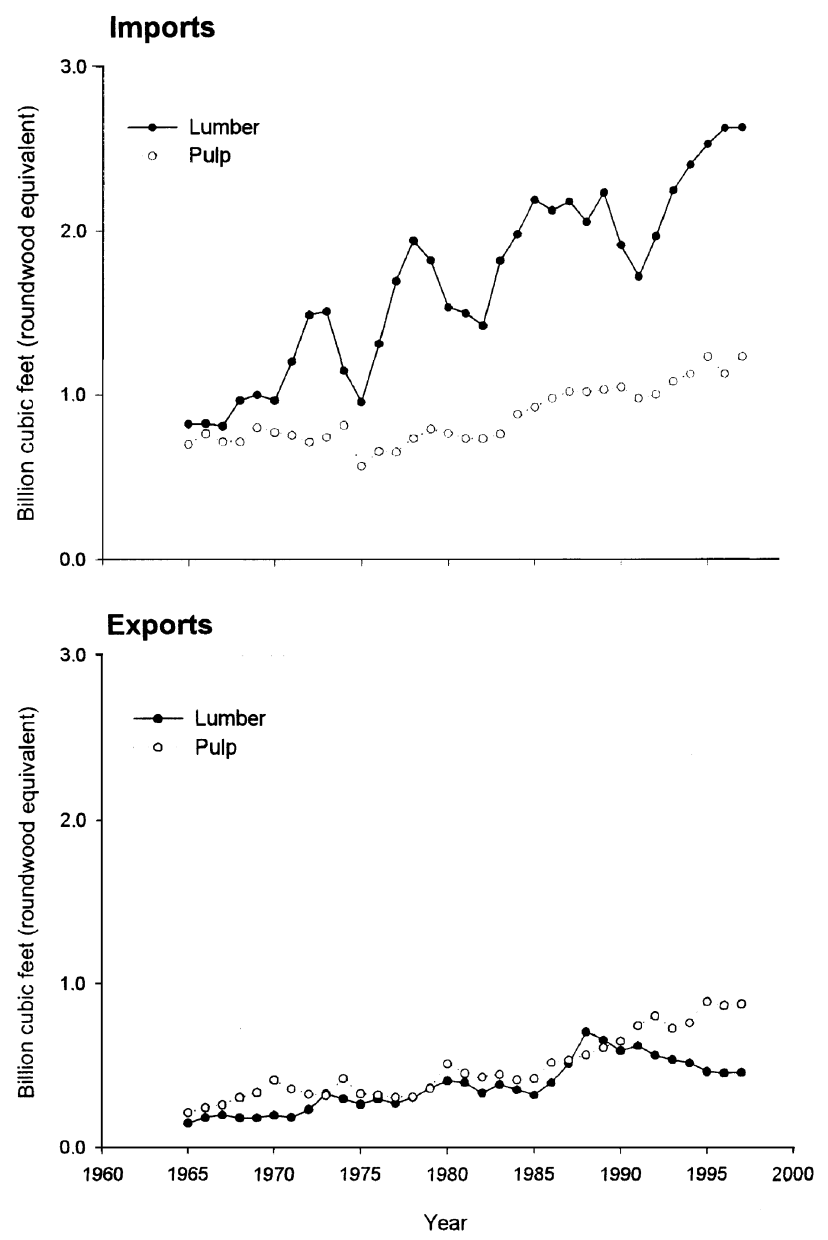

Figure I US wood imports and exports: 1965-97. Imports of both lumber and pulp exceed exports, indicating the reliance on foreign wood by the United States economy [Source: Howard (1999)]. 
Efforts to reduce domestic harvesting extend nationally. Harvesting in national forests has decreased by $70 \%$ since the mid-1980s to reach the lowest level since World War II (SAF, 2000) and some organizations and individuals are pushing for a complete ban. Meanwhile, local municipalities across the US have passed local bylaws regulating harvesting on private lands.

Such US domestic environmental protection may exert profound, although oftentimes unintended, impacts on the global environment including logging of previously inaccessible tropical and boreal forests (SAF, 1999). A recent study found that $c .1$ ha of primary forest (i.e. forest that has never been harvested before) in Asia, South America, Africa and Russia is logged for every 20 ha of forest protected from harvest in North America and Europe (Sohngen et al., 1999). Harvesting these remote forest areas requires the construction of roads that make them accessible for broadscale conversion to agriculture and other uses (Mather, 1990; Kittredge, 1996; United Nations Food and Agricultural Organization (UNFAO), 1997).

Consequently, it is imperative that environmental stewards go beyond the question of which areas to protect, to ask what resources in what quantities should be produced and where they should be obtained. Furthermore, options must be evaluated to minimize environmental impacts beyond individual backyards and across the globe.

\section{STRATEGIES FOR MEETING WOOD NEEDS AND REDUCING STRESSES ON FORESTS}

There are several strategies that the US could employ to address its wood needs and reduce forest impacts, including: (1) substitute other products for wood, (2) reduce natural resource consumption, (3) increase wood imports, (4) increase protection of forested areas, and (5) intensify local wood production (Bowyer, 1994; Dekker-Robertson \& Libby, 1998). These options vary in feasibility and global environmental impact.

\section{Strategy I: increase the use of wood substitutes}

Several materials may substitute for wood in paper production and construction, although most incur increased environmental costs. Pulp constitutes about $30 \%$ of US wood consumption and may be replaced by agricultural products and waste (Bielski, 1996; Howard, 1999). However, production of these replacements requires massive fibre plantations that contribute even less to biodiversity than tree plantations and generally require intensive chemical applications (Dekker-Robertson \& Libby, 1998). Although steel, concrete and aluminium may replace wood in construction, these materials also incur serious environmental, transportation and energy costs (Bowyer, 1994). Lumber is the least energy intensive construction material and its production releases significantly less carbon dioxide and toxic products than substitutes (Table 1). In addition, wood is renewable and forest growth may contribute to carbon sequestration, thereby yielding even greater trade-offs.
Table I Energy use by material

\begin{tabular}{lcc}
\hline Material & $\begin{array}{l}\text { Fossil fuel energy } \\
\left(\mathrm{MJ} \mathrm{kg}^{-1}\right)\end{array}$ & $\begin{array}{l}\text { Fossil fuel energy } \\
\left(\mathrm{MJ} \mathrm{m}^{-3}\right)\end{array}$ \\
\hline Rough sawn timber & 1.5 & 750 \\
Concrete & 2 & 4800 \\
Steel & 65 & 266,000 \\
Aluminium & 435 & $1,100,000$ \\
\hline
\end{tabular}

Ferguson et al. (1996).

\section{Strategy 2: decrease wood consumption}

In the US there is vast opportunity to decrease per capita wood consumption; this remains the most straightforward way to reduce pressure on the world's forests. In all categories of wood use, American consumption rates are at least double the European rates and more than three times the global rates (UNFAO, 1997; Howard, 1999). Major reductions are especially possible in the areas of paper and housing. A $15 \%$ decrease in total wood use would be achieved if the US adopted European levels of paper use (AF \& PA, 1997; Howard, 1999). Meanwhile, over the past 30 years (1965-97), the average size of the American home has increased $44 \%$, to 2150 square feet, while average occupancy has dropped $21 \%$ to 2.6 people (Howard, 1999; http://www.census.gov/). US homes average 1.7-2.2 times larger than in the UK and Japan (Wolff, 1992). Lumber accounts for nearly $50 \%$ of US wood consumption, with $30 \%$ of this used for new housing (Howard, 1999; RPA, 2001). Consequently, if US homes were to return to 1960 s size (or to that of England or Japan), per capita wood consumption would decrease by about 5\% (Howard, 1999; RPA, 2001).

Wood consumption could be reduced further through increased recycling. Recycling rates for solid wood and fibre are low compared with most materials (Bowyer, 1997). Paper recycling in the US is $45 \%$, well short of the $70 \%$ rate in Germany and Austria (US EPA, 1998; Environment Watch, 1997; Fig. 2). Although the reduction in virgin wood demand afforded by recycling is relatively low compared with increases in global demand (Dekker-Robertson \& Libby, 1998), increased wood recycling would still ease the pressure on the world's forests.

\section{Strategy 3: import more wood}

Increasing wood supplies from other parts of the world could meet short-term needs. However, major future suppliers, including Canada and Siberia for softwoods and tropical countries for hardwoods, are where the environmental effects of harvesting are generally more severe than in the north-eastern US (Bowyer, 1994, 1997).

British Columbia, Canada's main source of exports (Garner, 1991), supports more than half of the old-growth temperate rain forest in North America (SLDF, 2000). The environmental cost of wood from these forests is the loss of a unique ecosystem. Although Siberia offers a new and large 


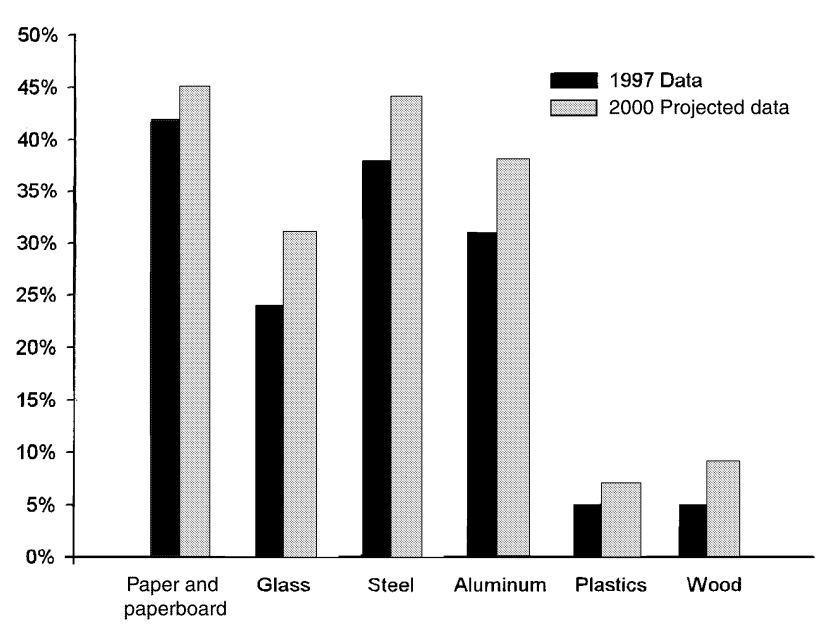

Figure 2 US recycling rates by material. Although paper and paperboard recycling rates are relatively strong, rates for solid wood and plastics lag well behind [Source: US EPA (1998)].

source of wood, this may come with major economic and environmental concerns (Bowyer, 1995). Because of outmoded Russian technology, up to $40 \%$ of material harvested in Siberia is wasted relative to US standards (Lippke, 1992; as cited in Dekker-Robertson \& Libby, 1998). Transportation from this remote location has high energy costs. But the greatest argument against harvesting in Siberia is ecological: in this land of deep permafrost, trees are small and grow slowly, rotation lengths are extremely long and immense harvesting areas are required.

The tropics, especially Indonesia, Malaysia and Brazil, are a growing source of hardwoods (ITTO, 1999). These regions experience severe environmental impacts including the logging of primary forests, land-use conversion and wildlife persecution. Wood importation from these regions also introduces exotic pests and pathogens, such as the Asian Longhorn beetle (USDA Forest Service, 2002).

\section{Strategy 4: increase protection of forested areas}

Through population growth, land conversion and a haphazard pattern of harvesting, forest area and the size of unmanaged and managed forest parcels are dwindling. Habitats supporting uncommon species and large intact forest blocks need to be protected to maintain ageing ecosystems, promote old-growth and other uncommon communities, and support natural ecological patterns and processes. Protected natural areas will increase in importance as refugia for taxa, communities, and processes that can also serve as benchmarks against which other areas can be compared. Meanwhile, in order to produce timber products, other large areas need to be identified and conserved for intensive management. As both unmanaged and managed forests may provide different, although complementary habitat and environmental benefits, the selection of these areas needs to be undertaken with a broad perspective.

\section{Strategy 5: increased US forest management}

Intensive US forest management has the potential to address some environmental and social needs (Brooks et al., 1992; Winjum et al., 1993; Bowyer, 1997; Dekker-Robertson \& Libby, 1998; Sohngen et al., 1999) and provide benefits including: (1) offset forest losses through conservative reforestation and agroforestry, (2) carbon sequestration (United Nations Climate Change Bulletin, 1997), (3) maintain diverse woodland habitats and (4) connect people to the environment and natural resources.

The US has the resources, economy and environmental oversight to develop a broad programme of sustainable forest management. However, a major question looms: will the American public allow the intensive management necessary to provide higher supplies of wood and will timber suppliers pursue this in an environmentally sound fashion? Through individual decision-making on private lands, engagement in planning on public lands and involvement in the regulatory arenas, Americans can exert a significant influence on wood production. Concerns with logging are not unwarranted and range from clear-cutting, herbicide use and highgrading of forests to ill-conceived and excessive road building in sensitive areas (Durbin, 1996). Environmental analysis is critical both in identifying unharvested areas and to meet rising wood demand.

\section{A THREEFOLD SOLUTION}

Clearly no simple solution exists for meeting global wood needs, improving equity in resource production/consumption and protecting the environment. However, a threefold approach may be a useful starting point:

(1) Decrease consumption of wood products (and substitutes) for paper and construction;

(2) Increase recycling rates of wood fibre, solid wood and paper products;

(3) Pursue a balanced approach to forest conservation based on large forest preserves, increased and sustainable production from native forests and intensive management of plantations.

\section{WHY FOCUS ON MASSACHUSETTS?}

To consider further the Illusion of Preservation and a global strategy for sound resource management, we focus on Massachusetts, the eighth most forested state in the nation, and an affluent region with consumption rates that are among the highest in the US. Forest harvesting rates are relatively low in Massachusetts and the vast majority of local wood needs are met through imports. Environmental concern is high throughout New England, and ironically, although not surprisingly, the citizens of Massachusetts have little interest in seeing 'their' forests harvested for wood products. A recommendation for more intensive management of these resources is certain to have a largely negative reception. 
Could Massachusetts balance more of its wood consumption with environmentally sustainable production? Yes, but one challenge may be getting 'well-intentioned people to understand that their decision to not cut wood locally often does great damage to the things they value someplace else' (W. Libby, personal communication). Seventy-eight per cent of the state's forests are owned by non-industrial individuals and families, each faced with many management options (Alerich, 2000). The challenge may be to connect these individuals with the global consequences of their decisions and to expose the illusion of natural resource preservation.

\section{The forest resource of Massachusetts: functional and ecological dimensions}

Massachusetts is heavily forested, despite the fact that 785 people per square mile make it the third most densely populated state in the nation (US Census, 2000; Hall et al., 2002). The state contains 3.1 million acres of forest covering $62 \%$ of the land area (Alerich, 2000). A full $85 \%$ of those forested acres is classified as timberland (i.e. capable of growing more than 20 cubic feet $\mathrm{acre}^{-1}$ year $^{-1}$, and not withdrawn from harvesting) according to the USDA Forest Service.

These forests are a legacy of historical patterns of natural and human disturbance. In the mid-nineteenth century, nearly $70 \%$ of the land was cleared for agriculture and remaining forest was cut, burned and grazed (O'Keefe \& Foster, 1998). In the late 1800s, agriculture declined and second-growth forests dominated by white pine established across the region's abandoned farmland. This supply of 'oldfield' white pine spurred a timber harvest boom that peaked in 1910-11 and yielded even-aged stands of predominantly hardwoods (Fig. 3; Steer, 1948; O’Keefe \& Foster, 1998). White pine is especially susceptible to windthrow and the 1938 hurricane continued the process of forest conversion from pine to even-aged hardwoods. Today, the most common tree species are red maple, eastern hemlock and white pine (Alerich, 2000; Hall et al., 2002).

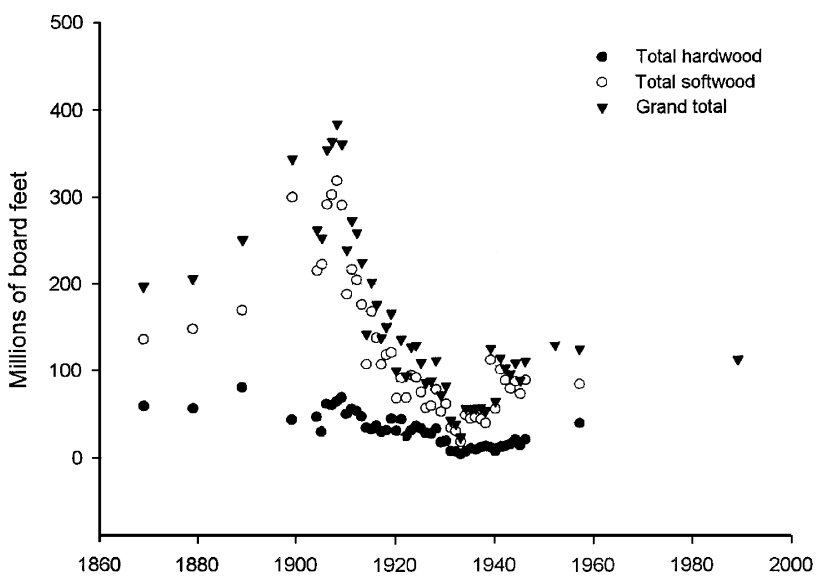

Figure 3 Reported Massachusetts lumber production 1869-1996. Softwood lumber production peaks at the turn of the last century, based on white pine stands that had been established on abandoned agricultural land following the height of farming around 1830 . Softwood lumber production also jumps based on salvage following the 1938 hurricane [Source: Steer (1948); Bond (1962); MA DEM (1997)].

Since 1938, logging and forest succession have been the main forces shaping forest composition. However, harvesting has not kept pace with tree growth since at least 1957 (Bond, 1991), and over the past three decades (1972-98) wood volumes have increased by $105 \%$ for softwoods and $149 \%$ for hardwoods (Dickson \& McAfee, 1988; Alerich, 2000). Since 1985 , sawtimber volume has increased by $41 \%$. Currently, average annual growth is 99.9 million cubic feet, whereas annual removals average 52.3 million cubic feet (see Fig. 4; Alerich, 2000). The history of lumber production (1869 and 1996) corroborates the high productivity of these forests (Fig. 3). In spite of the fact that little of the landscape was in mature forest in 1869 , lumber production was twice what it currently is (O'Keefe \& Foster, 1998). Given the aggressive way that these temperate forests rebound from
Figure 4 Net volume of sawtimber per acre of timberland, by diameter class: 1953, 1972, 1985, 1998. Sawtimber volumes per acre have increased dramatically in the last 50 years, even after accounting for removals through mortality or harvesting [Source: Dickson \& McAfee (1988); Alerich (2000)].

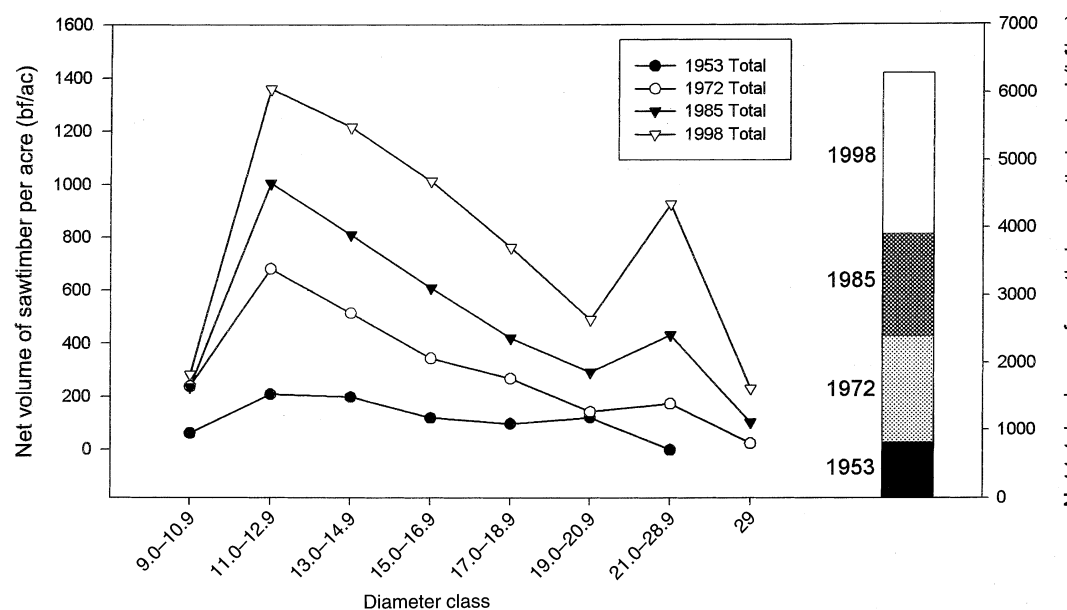


disturbance and regenerate naturally, it is logical to look at the extent to which this resource can meet some of the consumptive need for wood.

\section{The Massachusetts wood consumption-production ratio}

Haphazard and oftentimes poor forest management, coupled with a prosperous standard of living, confirm that Massachusetts has embraced the 'illusion of natural resource preservation'. International comparisons highlight the consumption-production disparity. Massachusetts is comparable with Germany, Switzerland, Japan and France in forest cover and the ratio of human population to forest area (see Fig. 5). Yet, assuming that the US averages apply to Massachusetts (a conservative assumption given the state's high standard of living), per capita consumption is three to four times the level in these countries (Fig. 6). Meanwhile, Japan (a wood-importing nation) harvests nearly five times the wood volume per hectare of forest than Massachusetts and Germany's harvest rate is seventeen times greater (Fig. 6). As in other populated areas of the US, there is little connection between lifestyle and resource production in Massachusetts.

\section{The lumber market in Massachusetts}

Massachusetts currently generates a small amount of structural lumber primarily from white pine, which is light, strong and easily worked. The other major softwood species is hemlock, which is used less frequently for framing and home construction (Drath, 1947). These two species could substitute in many applications for Douglas fir and Sitka spruce from the Pacific North-west. More than half of the lumber sawn in Massachusetts is oak, which is highly valued for furniture and other uses (Bond, 1991). However, red

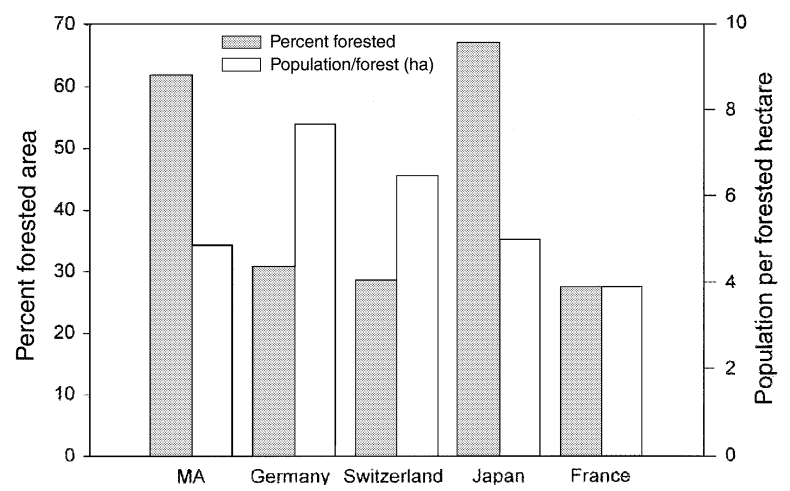

Figure 5 Comparison of percentage forested area and population density per forested area: Massachusetts, Germany, Switzerland, Japan and France. Massachusetts is more than $60 \%$ forested by area and experiences a population density per forest area comparable with Japan and France [Source: Massachusetts, Alerich, 2000; other nations, World Resources Inst. (1998), World Resources Institute, http://www.wri.org/wr-98-99/index.html].

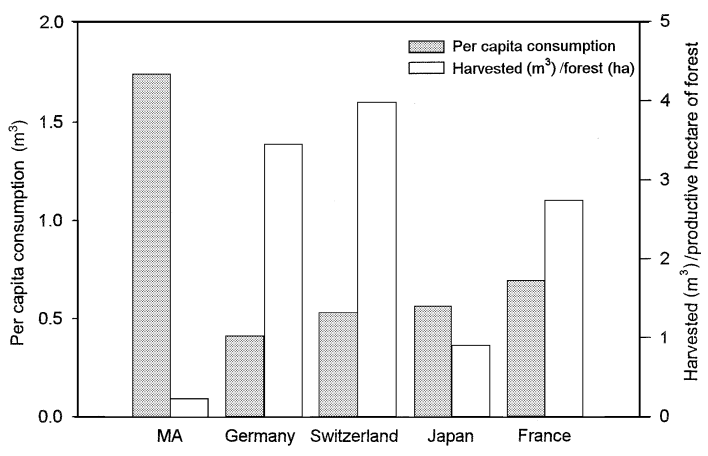

Figure 6 Per capita wood consumption and harvest per forested area: Massachusetts, Germany, Switzerland, Japan and France. Although relatively heavily forested, harvesting per unit area from Massachusetts forests is low compared with other countries. In contrast, per capita consumption of wood is several times greater in Massachusetts. [Source: Massachusetts, DEM; Howard (1997); Alerich (2000); MISER; Other nations, FAO (2000), http://apps. fao.org].

maple, the most common species, is barely utilized, despite its potential to substitute for imported wood in the construction of flooring, furniture and polymer-plastic products (Damery, 1999).

\section{Shifting the consumption-production ratio}

Harvest volumes in Massachusetts are low and only equalling about $2 \%$ of wood consumption gauged by national rates (Fig. 7; Howard, 1999). Additional wood (exact volumes are unknown) is produced by the one-time conversion of forest to other developed uses as the USDA Forest Service estimated a loss of 281,000 acres of timberlands between 1985 and 1998 (i.e. 20,071 acres annually; Alerich, 2000). Forest Service FIA results indicate an average of 6282 board feet acre $^{-1}$ of timberland.

Estimates of wood consumption in Massachusetts are based on overall American per capita consumption rates (Howard, 1999) and the current Massachusetts population. Consumption is estimated to be the simple difference between the amount of wood that the United States produces, imports and exports. Consequently, consumption in this case simply refers to the amount of wood product used and does not incorporate estimates of recycling. Given this disparity between production from Massachusetts forestland and consumption, would increased harvesting make a difference? Below we examine this question under different management and consumption scenarios.

We estimate potential sustainable harvest levels based on statewide estimates of forest growth. An analysis of indirect evidence suggests a regional growth rate and corresponding rough estimate for sustainable harvesting of 275-350 board feet acre $^{-1}$ year $^{-1}$ (1.0-1.2 $\mathrm{m}^{3}$ acre $^{-1}$ year $^{-1}$ ) (Berlik et al., 2002). Based on this estimate it is possible to illustrate several timber management production scenarios for public and private forestland in Massachusetts compared with: the total 


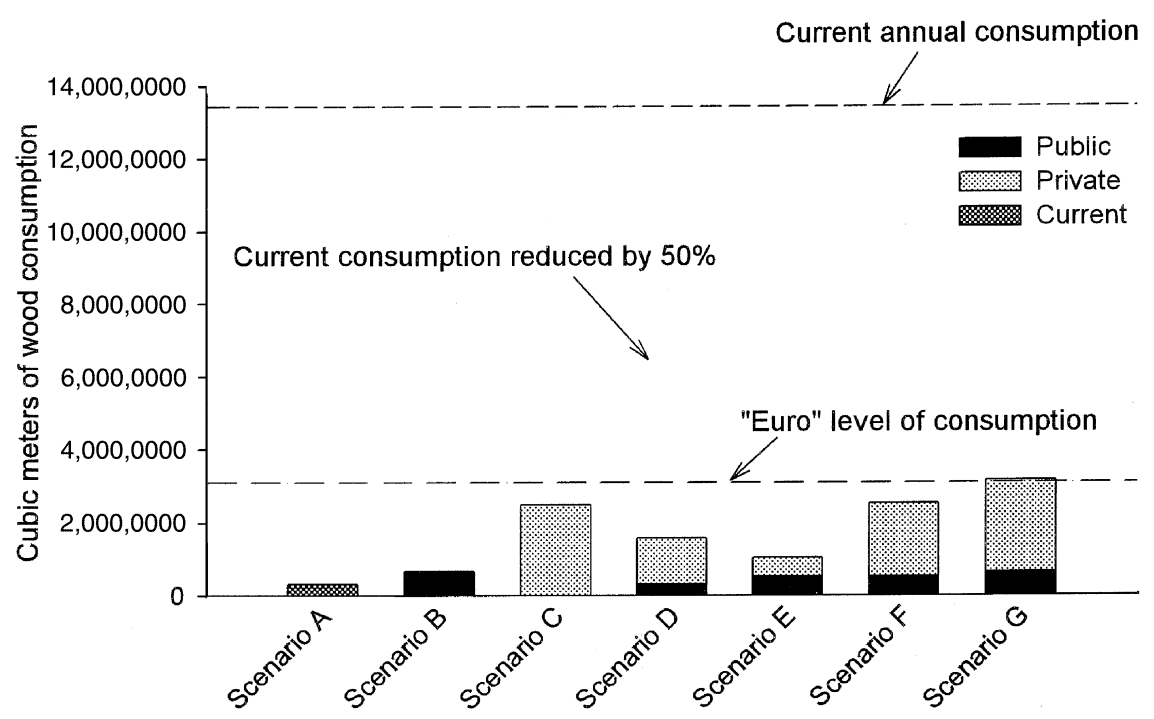

Figure 7 Massachusetts's hypothetical harvest scenarios compared with different levels of statewide consumption $\left(\mathrm{m}^{3}\right.$ year $\left.{ }^{-1}\right)$. The current annual harvest contributes little to meeting the estimated consumption of wood products in Massachusetts. Through potential decreases in consumption, coupled with various approaches to increased timber management on public and private lands, the gap between production and consumption can be made smaller. Scenario A: current annual MA harvest of 311,190 $\mathrm{m}^{3}$. Scenario B: $100 \%$ timber management of public land, $0 \%$ timber management of private land. Scenario C: $0 \%$ timber management of public land, $100 \%$ timber management of private land. Scenario D: $50 \%$ timber management of public land, $50 \%$ timber management of private land. Scenario E: $80 \%$ timber management of public land, $20 \%$ timber management of private land. Scenario F: $80 \%$ timber management of public land, $80 \%$ timber management of private land. Scenario G: $100 \%$ timber management of public land, $100 \%$ timber management of private land.

statewide wood per capita consumption volumes at current rates $\left(2.1 \mathrm{~m}^{3}\right.$ year $\left.{ }^{-1}\right)$, current per capita rates reduced by $50 \%\left(1.05 \mathrm{~m}^{3}\right.$ year $\left.^{-1}\right)$; and the 'European' per capita level of $0.5 \mathrm{~m}^{3}$ year $^{-1}$ (Fig. 7).

In the most extreme scenario (Scenario $G$ in Fig. 7), Massachusetts could produce the equivalent of its annual wood consumption if all of its public and private forestland were managed for timber at the estimated sustainable rate of $1.2 \mathrm{~m}^{3}$ acre $^{-1}$ year $^{-1}$ (or 340 board feet acre $^{-1}$ year $^{-1}$ ), and consumption was reduced to 'European levels', i.e. per capita rate of $0.5 \mathrm{~m}^{3}$ year $^{-1}$. This scenario of 'self-sufficiency' is unrealistic, as more than $75 \%$ of the forest is owned by hundreds of thousands of private individuals, precluding unanimity in timber management.

If all private forests and no public forestland were to be managed sustainably $\left(1.2 \mathrm{~m}^{3}\right.$ acre $^{-1}$ year $^{-1}$ on average $)$ for timber (Scenario C; Fig. 7), 20\% of consumption could be matched with sustainable production. This aggressive scenario would be less stringent than current Swedish forest management policy where both private and public forest is considered a national resource, to 'be managed in such a way as to provide a valuable yield and at the same time preserve biodiversity' (Swedish Forestry Act: http://www.svo.se/eng/ act.htm). If Massachusetts' consumption levels were reduced by $50 \%$ under Scenario C, $40 \%$ of annual statewide consumption could be met. In the unlikely event that consumption levels were reduced to European levels, $82 \%$ of consumption could be met.

A more realistic scenario would involve a combination of private and public forest management for timber. If $50 \%$ of public forestland and $50 \%$ of private forestland were managed at the estimated sustainable harvesting rate (Scenario D in Fig. 7), Massachusetts could match $12 \%$ of current consumption, as much as $25 \%$ with current consumption reduced by half, and fully $52 \%$ of consumption at European consumption rates. Such a scenario would still allow the landscape to support extensive blocks of undisturbed forest. Achieving a $25 \%$ consumption-production ratio from the current $2 \%$ level through strategic harvesting and aggressive cuts in consumption would have the potential of providing an immense service to the global environment.

\section{ECOLOGICAL CONSIDERATIONS}

What might be the ecological consequences of much more intensive forest management in an eastern US state like Massachusetts? Could such management be accomplished in a fashion mindful of public concern for the local environment while also aiding the global environment?

\section{Regulatory oversight}

In broad theory, if not in all practice, Massachusetts is well ahead of the north-western and south-eastern US, British Columbia and other major source areas in terms of regulatory oversight of cutting practices for public and private land (Ellefson \& Chang, 1994; Kittredge et al., 1999). In Massachusetts, environmental oversight of harvesting is provided by a forest cutting practices act, a state endangered species act, a wetlands protection act, a rivers protection act, an 
old-growth policy and required programmes in both forester and logger licensing.

The Forest Cutting Practices Act (Chapter 132) requires a detailed cutting plan and site review by a state forester before each harvest (Kittredge \& Parker, 1995) to prevent negative impacts on wetlands, water quality, or rare or endangered species. Guidelines include standards for tree cutting to promote rapid regeneration, logging road regulations to prevent erosion and sedimentation, and buffer strip requirements to protect the visual quality of the landscape and the health of water bodies and certified vernal pools (Kittredge \& Parker, 1995).

The Rivers Protection Act regulates harvesting activities in the 200-foot strip along all perennial streams. The Massachusetts Endangered Species Act protects the 173 animal species and 251 plant species currently listed as endangered, threatened or of special concern (MA NHESP, 1999). The Wetlands Protection Act bars alterations to wetland habitats that will have an adverse effect on rare wildlife species (MA NHESP, 1999). A DEM policy excludes harvesting on all areas of old growth on its lands (MA DEM, 1998).

In contrast to most states, Massachusetts' Forest Cutting Practices Act restricts harvesting to licensed timber harvesters, which requires knowledge of regulations and continuing education annually. Similarly, professional foresters require a license based on formal education from a Society of American Foresters accredited university programme, and several years of professional experience, defined by regulation. Both licenses are revocable if regulations are violated.

\section{Forest resiliency, nutrient retention and biodiversity}

The resiliency of the northern temperate forest makes it well suited for forest management. Following harvesting, native forest cover quickly re-establishes, as evidenced by rapid re-growth after nineteenth century agriculture, the 1938 hurricane, and repeated episodes of logging and fire. Gentle topography and rapid succession minimize erosion and nutrient loss and the vigorous young forests that follow harvesting retain nutrients and store large amounts of carbon (Vitousek \& Reiners, 1975; Borman \& Likens, 1979).

Although logging is often insincerely legitimized as promoting wildlife habitat, it may be an important tool for managing biodiversity. For example, many of the most rapidly declining species in the north-east are associated with early successional habitat of grassland, shrublands and young forestland that were more abundant in the nineteenth century (Foster et al., 2002). Management can be used to maintain such landscapes or to enhance particular species such as oak, which is valuable for wildlife as well as timber.

\section{CONFRONTING THE ILLUSION OF PRESERVATION: POTENTIAL STRATEGIES FOR MASSACHUSETTS AND BEYOND}

Management of the 2.6 million acres of timberland in Massachusetts is determined by the decisions of more than 235,000 private families and individuals, as well as various agencies, communities and non-profit groups (Dickson \& McAfee, 1988). Private owners are relatively free to manage their land according to their personal goals. All evidence suggests that southern New England landowners are far more interested in residential and recreational uses of the forest including privacy, aesthetics and wildlife habitat than timber production (Kingsley, 1976; Archey \& MacConnell, 1982; Alexander, 1986; Lindsay et al., 1992; Rickenbach et al., 1998). Few individuals owning less than twenty-five acres of forestland intend to cut trees for timber (Tyson et al., 1998). Given these landowners' attitudes would it be possible to reduce Massachusetts' wood consumption and imports and increase interest in local forest management? The following discussion reviews the key barrier to 'confronting the illusion' and suggests directions towards a solution.

\section{Social attitudes - a major barrier to confronting the 'Illusion'}

Major factors driving the low intensity of forest management include lack of information and incentive and social attitudes that scorn harvesting. Philosophical objections to harvesting are widespread as indicated by polls showing that $63 \%$ of Americans feel that there is not enough wilderness protected on national forests and $70 \%$ favour a ban on logging in national forest roadless areas (The Wilderness Society, 1999). A majority of people believes that logging is worse than non-management for the environment and favour increased protectionism.

Local regulatory systems also impede management. In Massachusetts alone there are more than thirty-five individual and idiosyncratic town bylaws that control timber harvesting.

Deep-seated philosophical objections to harvesting are probably the greatest barrier to changing owners' approach to forest management. As long as the global consequences of consumption are ignored, protectionism is heralded and logging is viewed negatively (especially in one's backyard), efforts to reduce wood consumption or to encourage sound management in areas of low ecological impact may be fruitless. Such efforts will only succeed if they are coupled with a fundamental change in attitude that reconciles the important role of preservation with the reality that using wood means cutting trees - somewhere.

A global approach to preservation and conservation could be effective and responsible. Educators, environmental activists, politicians, among others, could promote the argument that reductions in wood consumption and wise management of resilient and productive forests would be good for the global environment. Massachusetts can be examined as a case study: consumption soars above the rest of the world and the mature forest landscape is lightly and poorly managed, while staggering areas of pristine and less resilient forests are being cut and degraded elsewhere.

Solution 1: reduce wood consumption

Massachusetts residents could immediately reduce wood consumption by cutting paper usage and housing size, which 
account for $45 \%$ of use (Howard, 1999). Reducing paper consumption to European levels would decrease per capita wood consumption by $15 \%$; decreasing the average home size to 1960 s levels would result in an additional 5\% reduction (AF \& PA, 1997; Howard, 1999).

\section{Solution 2: increase wood recycling}

Massachusetts has successful recycling programmes for paper, plastics and beverage containers. Currently, 95\% of municipalities offer such programmes; the recycling rate for newspaper, cardboard, glass, bottles, cans, scrap metal and recyclable plastics is $34 \%$ with a near-term goal of $46 \%$ (AF \& PA, 1997; MassRecycle, 2000). The recycling rate for paper in Massachusetts is between $43 \%$ and $60 \%$ (NE Recycling Council; US Census, 2000; MA DEP, 2002), compared with the national rate of $42 \%$ (US EPA, 1998). However, Germany and Austria recycle $70 \%$ of paper indicating that further achievements are possible. Furthermore, wood fibre and solid wood are not commonly included in Massachusetts' recycling programmes and the national recycling rate for solid wood is less than $10 \%$ (US EPA, 1998).

\section{Solution 3: conserve forested environments and protect critical ecological resources}

The greatest threat to Massachusetts' forests remains conversion to non-forest uses; countering this trend should be a major priority. Timberland in Massachusetts decreased by $9.6 \%$ from 1985 to 1998 , a trend that is expected to continue (Alerich, 2000). In addition, if Massachusetts increases harvesting, there are crucial areas that warrant complete protection, such as wetlands, old growth forests, endangered species habitat, uncommon communities, and large areas necessary to support landscape-level processes and wideranging interior forest species. There is great need for conservation of all remaining forests followed by regional planning and strategic selection of areas for intensive management, wildland protection, diverse recreation and other attributes.

\section{Solution 4: encourage sustainable production in suitable areas}

There are many positive values to good forestry on private lands. Neighbourhoods and local residents enjoy the scenery, wildlife and healthy environment provided by well-managed forests. Forestland also incurs lower town service costs than developed land (SNEFCI, 1995). Yet the taxes on forestland do not reflect the shared advantages of a well-managed forest. Massachusetts could develop a tax structure that rewards landowners who are good stewards of the forest, regardless of the specific management approach. With the right arrangement of incentives, more landowners will become interested in owning forestland and practicing ecologically sustainable management for forest products.

Massachusetts' substantial timber supply lies in a matrix of public and private ownership. The potential exists for a forester Green Certification programme to encourage ecosystem-based management across property boundaries through collaborative management and cost-sharing (Campbell \& Kittredge, 1996; Leak et al., 1997). Green Certification is conveyed by a neutral third-party certifying agency that typically evaluates a company's timber harvesting practices according to its set of accepted standards of ecological impact (UN/ECE Timber Committee, 1997-98). Besides differentiating the wood product to the consumer in the market, this label can potentially translate into a slightly higher selling price (UN/ECE Timber Committee, 199798).

A new form of Green Certification has been accepted by the international certification body known as the Forest Stewardship Council (FSC), whereby Resource Managers are certified and multiple smaller properties in their care can fall under their certification. This approach is promising as it enables small owners to voluntarily enter their land into certification and attempts to keep costs low (Smartwood, 2001). If assemblages of landowners use a certified forester on a regional scale, then the total acreage becomes a more coordinated economic unit, rather than a collection of spatially and temporally separate operations, and hence a more reliable and viable means to harvest. By assuring that management is held to widely accepted environmental standards and monitored by third-party auditors, Green Certification may provide a means by which landowners may become more comfortable with harvesting.

\section{CONCLUSION}

Nearly 50 years ago, Ferguson \& Howard (1956) observed that the 'rate of production is far less than the lumber demands of Massachusetts consumers. They must import from other states about ten times as much lumber as the sawmills in the state produce. The lumber freight bill alone is a sizeable item. This large freight-cost advantage for local lumber producers is potentially a major incentive for growing more sawtimber closer to Massachusetts markets'. Although the issue addressed in this paper is clearly not new, the stakes are both different and higher. The 1956 concern for freight bills is dwarfed by concerns for the global environmental consequences of Massachusetts' consumption levels and sources of wood. We now have the opportunity to cut trees locally, in a heavily forested and ecologically resilient landscape, in order to reduce the impact on oftentimes more fragile and globally threatened forests.

In a state like Massachusetts, where $78 \%$ of all forest is privately owned, it is not likely that any single argument will alter patterns of natural resource use or production. The diversity of ownership attitudes, socioeconomic conditions and reactions to philosophical and financial incentives guarantee that there will always be owners who choose not to harvest. Can Massachusetts meet all its consumptive needs for wood locally? Not realistically. Can Massachusetts reduce its use of wood and its substitutes? Vastly. Can Massachusetts' forests contribute more to meet local wood demand on a sustainable basis? Absolutely. In so doing, are there global environmental benefits to be realized? Yes. 
Currently there is no environmental ethic focused on meeting wood needs locally and little criticism of consumption behaviour. Instead, an antilogging ethic reigns and degradation of the global environment ensues. A new environmental effort is needed to expose this illusion of preservation. This effort will depend primarily on greater discussions concerning the ethical implications of excessive consumption joined with indiscriminate protectionism. The message could become stronger and more locally relevant in the context of programmes that reduce wood use and encourage ecologically sound harvesting.

Management of forests is no longer as simple as knowing what you have, crafting goals and objectives, and designing management strategies to achieve them within the physical and biological constraints of the land. Removing forestland from the productive timber supply can have unintended consequences beyond the woodlot. The best management strategies today are those based on informed decisions - not only about the land, productivity and objectives - but also based on regional, national and global environmental and social consequences. This notion applies to a family considering options for their land, a land trust discussing alternatives for a newly acquired piece of property, a community studying alternatives for municipal holdings, even state and federal governments considering the management of public forestland. It is not the intention of this paper to promote the intensive production of timber on all forested lands, but to make a case for a bold reduction in wood use and a judicious and sustainable increase in locally produced wood.

\section{ACKNOWLEDGMENTS}

This paper has greatly benefited from information, suggestions and guidance provided by the following: David Damery, C. H. W. Foster, Lloyd Irland, William Libby, John O'Keefe, William Rivers, Jim Soper, Bruce Spencer, Brian Donohue and the Harvard Forest Laboratory group.

\section{REFERENCES}

Allen, S. (1998a) Are Maine's great woods on chopping block? The Boston Globe, November 9, 1998.

Allen, S. (1998b) Cheap oil will soon be memory, some say; Depleted reserves seen in coming decades. The Boston Globe, December 3, 1998.

Alerich, C.L. (2000) Forest statistics for Massachusetts: 1985 and 1998. USDA Forest Service Resource Bulletin, NE-148, 104.

Alexander, L. (1986) Nonindustrial private forest landowner relations to wildlife in New England. PhD Dissertation, Yale University, New Haven, CT.

American Forest and Paper Association (AF \& PA). December (1997) Paper recycling programs. http:www/afandpa.org/ recycling/paper/programs.html.

Archey, W.E. \& MacConnell, W.P. (1982) Forest landowner characteristics and attitudes in Berkshire County, Massachusetts. Massachusetts Agricultural Experiment Station Research Bulletin, No. 679, 52.
Berlik, M., Kittredge, D. \& Foster, D. (2002) The illusion of preservation, Harvard Forest Paper No. 26., Petersham, Massachusetts.

Bielski, V. (1996) Shopper spare that tree!' Sierra. July/August.

Bond, R.S. (1962) Marketing lumber from Massachusetts Sawmills. University of Massachusetts Agricultural Experiment Station Bulletin, No. 526, 58

Bond, R.S. (1991) Lumber production and marketing by Massachusetts Sawmills, 1989. Bureau of Forest Development, Division of Forests and Parks, Massachusetts Department of Environmental Management, MA, USA, pp. 46.

Bormann, F.H. \& Likens, G.E. (1979) Pattern and process in a forested ecosystem: disturbance, development, and the steady state based on the hubbard brook ecosystem study. SpringerVerlag, New York.

Bowyer, J. (1994) Raw materials, environment, and developed nations. Proceedings: Pacific Timber Engineering Conference, Gold Coast, Australia, July 11-15.

Bowyer, J. (1995) Wood and Other Raw Materials for the 21st century. Where will they come from? Forest Products Journal, 45, 17-24.

Bowyer, J. (1997) The role of renewable resources in the global raw materials picture. The Fourth International Conference on Woodfiber-Plastic Composites. May 12-14, 1997, Madison, Wisconson. Forest Products Society: pp. 259-267.

Bowyer, J. \& Stockmann, V.E. (2001) Agricultural residues: an exciting bio-based raw material for the global panels industry. Forest Products Journal, 51, 10-21.

Brooks, R.T., Kittredge, D.B. \& Alerich, C.L. (1992) Forest Resources of Southern New England. USFS Northeastern Forest Experiment Station Resource Bulletin, NE-127.

Campbell, S.M. \& Kittredge, D.B. (1996) Application of an ecosystem-based approach to management on multiple NIPF ownerships: a pilot project. Journal of Forestry, No. 2, 94.

Damery, D. (1999) Building materials and forest products marketing specialist. UMass, Amherst.

Dekker-Robertson, D.L. \& Libby, W.J. (1998) American forest policy - global ethical tradeoffs. Bioscience, 48, 471-477.

Dickson, D.R. \& McAfee, C.L. (1988) Forest Statistics for Massachusetts - 1972 and 1985. USDA Forest Service. Northeastern Forest Experiment Station Resource Bulletin, NE-106, 112.

Drath, W.H. (1947) Industrial uses of selected timber species. US Department of Commerce, Industrial Series no. 69, June.

Durbin, K. (1996) Tree huggers; victory, defeat and renewal in the northwest ancient forest campaign. The Mountaineers, Seattle.

Ellefson, P.V. \& Chang, A.S. (1994) State forest practice programs: regulation of private forestry comes of age. Journal of Forestry, 92, 34-37.

Environment Watch: Western Europe, September (1997) Cited in Friends of the Earth, 1998. Recycling schemes collapse across britain: government waste strategy in early crisis. 25 June 1998. http://www.foe.co.uk.

FAO (2000) United Nations Food and Agricultural Organization. http://www.fao.org/forestry/.

Ferguson, R.H. \& Howard, M.C. (1956) The Timber Resource in Massachusetts. USDA Forest Service, NE Forest Experiment Station Forest Survey, 45. 
Ferguson, I., La Fontaine, B., Vinden, P., Bren, L., Hateley, R. \& Hermesec, B. (1996) Environmental properties of timber. Research Paper Commissioned by the Forest and Wood Products Research and Development Corporation, http:// www.fwprdc.org.au/publications/online/epotbrochure/manufacture.htm.

Foster, D.R., Motzkin, G., Bernardos, D. \& Cardoza, J. (2002) Wildlife dynamics in the changing New England landscape, Journal of Biogeography, 29, 1337-1357.

Garner, J. (1991) Never under the table: a story of British Columbia's Forests and Government Mismanagement. Cinnabar Press, Nanaimo, British Columbia.

Hall, B., Motzkin, G., Foster, D.R., Syfert, M. \& Burk, J. (2002) Three hundred years of forest and land-use change in Massachusetts, USA, Journal of Biogeography, 29, 1319-1335.

Howard, J.L. (1997) US timber production, trade, consumption, and price statistics 1965-1994. USDA Forest Service General Technical Report, FPL-GTR-98.

Howard, J.L. (1999) US timber production, trade consumption, and price statistics 1965-1997. USDA Forest Service General Technical Report, FPL-GTR-116, 76.

ITTO (1999) Annual review and assessment of the world timber situation 1999. http://www.itto.or.jp/inside/review1999/index.html.

Kingsley, N.P. (1976) The forest land owners of Southern New England. USDA Forest Service Resource Bulletin, NE-41.

Kittredge, D.B. (1996) Changes in global forest distribution. Conservation of faunal diversity in forested lands (ed. R. M. DeGraaf and R. I. Miller), Chapman \& Hall, London.

Kittredge, D.B. \& Parker, M. (1995) Massachusetts forestry best management practices manual. Department of Environmental Management and the University of Massachusetts, MA, USA.

Kittredge, D.B., Rickenbach, M.G. \& Broderick, S.H. (1999) Regulation and stumpage prices: a tale of two states. Journal of Forestry, 97, 12-16.

Leak, W.B., Yamasaki, M., Kittredge, D.B. Jr, Lamson, N.I. \& Smith, M.L. (1997) Applied ecosystem management on nonindustrial forest land. USDA Forest Service General Technical Report, NE-239, Radnor, PA, 30.

Lindsay, J.J., Gilbert, A. \& Birch, T. (1992) Factors affecting the availability of wood energy from non-industrial private forest lands in the northeast. USDA Forest Service, Northeastern Forest Experiment Station, Resource Bulletin, NE-122.

Lippke, B.R. (1992) Meeting the need for environmental protection while satisfying the global demand for wood and other raw materials: a North American and Global Trade Perspective. Proceedings of Wood Product Demand and the Environment, pp. 137-142. 13-15 November 1991; Vancouver, Canada. Cited in Dekker-Robertson and Libby. 1998, 474.

MA DEM (1997) Directory of sawmills, dry kilns, and lumber treaters in Massachusetts. Bureau of Forestry, MA, USA.

MA DEM (1998) Old growth policy. Final Draft 23 October. Division of Forest and Parks, Bureau of Forestry, MA, USA.

MA DEP (2002) http://www.state.ma.us/Department/recycle/ recycle.htm.

MassRecycle (2000) http://www.massrecyclesday.org.
Mather, A.S. (1990) Global forest resources. Timber Press, Oregon, Portland.

MISER: Massachusetts Institute for Social and economic Research, University of Massachusetts, http://www.umass. edu/miser/.

Northeast Recycling Council: http://www.nerc.org/.

O'Keefe, J. \& Foster, D. (1998) An ecological and environmental history of Massachusetts forests. Stepping back to look forward (ed. Charles H.W. Foster), pp. 19-66. Harvard College, MA, USA.

Rickenbach, M.G., Kittredge, D.B., Dennis, D. \& Stevens, T. (1998) Ecosystem management: capturing the concept for woodland owners. Journal of Forestry, 96, 18-24.

RPA (2001) Timber assessment draft review. January 2001.

SAF (1999) Issue of The Forestry Source. July/August 1999.

SAF (2000) Sierra Nevada plan reduces harvesting. June 2000.

Sierra Legal Defense Fund (2000) http://www.sierralegal.org/ issue/forest_facts.html.

Smartwood. http://www.smartwood.org/.

Sohngen, B., Mendelsohn, R. \& Sedjo, R. (1999) Forest management, conservation, and global timber markets. American Journal of Agricultural Economics, 81, 1-13.

Solberg, B. (1996) Long-term trends and prospects in world supply and demand for wood and implications for sustainable forest management. Report for the Intergovernmental Panel on Forests (IPF) of the UN Commission for Sustainable Development Research Report no. 6. European Forestry Institute.

Southern New England Forest Consortium, Inc, (SNEFCI) (1995) Cost of community services in southern New England. Chepachet, RI, USA

Steer, H.B. (1948) Lumber production in the United States: 1799-1946. USDA Miscellaneous Publication, No. 669.

The Massachusetts Natural Heritage and Endangered Species Program (MA NHESP). July 11 (1999) http://www.state.ma.us/dfwele.

The Wilderness Society Newsroom, July 27 (1999) Roadless protection favored by overwhelming majority of Americans. http://www.wilderness.org/newsroom/index.htm.

Tromborg, E., Buongiorno, J. \& Soberg, B. (2000) The global timber market: implications of changes in economic growth, timber supply, and technological trends. Forest Policy and Economics, 1, 53-69.

Tyson, B., Campbell, S. \& Grady, E.S. (1998) Woodcaping for small landowners in southern New England. Journal of Forestry, 96(12), 4-9.

US Census (2000) http://factfinder.census.gov/servlet/BasicFactsServlet.

UN/ECE (1997-98) Timber Committee. Forest products annual market review. Timber Bulletin, LI, ECE/TIM/ BULL $/ 51 / 3$.

United Nations Climate Change Bulletin (1997) Issue 15, $4^{\text {th }}$ quarter. Information Unit for Conventions (IUC), United Nations Environment Programme.

United Nations Food and Agricultural Organization (UNFAO) (1997) State of the world's forests. Rome.

US EPA (1998) Characterization of MSW in the US: 1998 update. Washington DC. 
USDA Forest Service (2002) Asian Longhorned Beetle fact sheet. http://www.exoticforestpests.org/english/Detail.CFM? tblEntry_PestID=53.

Vitousek, P.M. \& Reiners, W.A. (1975) Ecosystem succession and nutrient retention: a hypothesis. Bioscience, 25, 376-381.

Winjum, J.K., Meganck, R.A. \& Dixon, R.K. (1993) Expanding global forest management: an 'easy first' proposal. Journal of Forestry, 91, 38-42.
Wolff, M. (1992) Where we stand: can America make it in the global race for wealth, health, and happiness? Bantam Books, New York.

World Forest Institute. North American Forest Products Trade. http://www.vpm.com/wfi/trade.

World Resources Institute (1998) World Resources 1998-99: a guide to the global environment. pp. 369. Oxford University Press, New York, Oxford.

\section{BIOSKETCHES}

Mary M. Berlik studied Environmental Science and Public Policy at Harvard University and wrote her senior thesis on

Massachusetts forest policy in the context of global natural resource conservation. She is currently pursuing a career in medicine.

David B. Kittredge serves as the Forest Policy Analyst at the Harvard Forest and on the forestry faculty in the Department of Natural Resources Conservation at the University of Massachusetts, Amherst.

David R. Foster is director of the Harvard Forest where he studies long-term forest dynamics resulting from human and natural disturbance and environmental change. 